\title{
AVRUPA BiRLiĞi TEMEL HAKLAR ŞARTI
}

\author{
Dr. Yüksel Metin \\ Süleyman Demirel Üniversitesi \\ Iktisadi ve Idari Bilimler Fakültesi
}

\section{Özet}

Bu şalışmada Avrupa Birliği Temel Haklar Şartı'nın amacı, hazırlık süreci, içeriği ve hukuki bağlayıcılığı ele alınacaktır. Bu bağlamda Avrupa Birliği'nin bir temel haklar kataloğuna gereksinimi bulunup bulunmadığı ve Şart'ın Avrupa Birliği Anayasasının temelini teşkil edip etmeyeceği gibi ఢ̧eşitli sorunlara değinilecektir. Konunun daha iyi anlaşılması için öncelikle Avrupa Birliği çerçevesinde temel hak korumasının gelişimine kısaca değinilecektir.

\section{Charter of Fundamental Rights of the European Union}

\section{Abstract}

In this study, the purpose, preparation process, content and legal binding of the Charter of Fundamental Rights of the European Union are dealt with. In this regard, some questions whether the European Union needs a catalogue of fundamental rights, and whether the Charter constitutes the basis of the European Union Constitution will be mentioned. For more appropriate understanding of the subject, the development of the protection of fundamental right, will firstly be examined within the framework of the EU. 


\section{Avrupa Birliği Temel Haklar Şartı}

\section{Gikiş}

İkinci Dünya Savaşından sonra Avrupa'da barışı hakim kılmak ve Avrupa ülkeleri arasında işbirliği ve dayanışmayı gerçekleştirmek üzere kurulan AET, sınırların kalktığı bir ortak pazar ve ortak para sistemini adım adım hayata geçirmiştir. Gittikçe ilerleyen entegrasyon sonucu bugün $A B$ yalnuzca ekonomik alanda değil, ayn zamanda siyasal alanda da bir bütünleşmeyi amaçlamaktadır. Kısacası $A B$, ekonomik, siyasal ve anayasal bir bütünleşmeyi ifade eder hale gelmektedir. 7 Aralık 2000 tarihinde Nice zirvesinde Avrupa Parlamentosu, Konsey ve Komisyon başkanları tarafından imzalanarak törenle ilan edilen Temel Haklar Şartı, AB'nin hedeflediği bu yolda önemli bir adım teşkil etmektedir (DAEBLER-GMELIN, 2000: paragraf 3).

Temel Haklar Şartı, temel hakları daha anlaşlır bir şekilde formüle etme ve temel haklara daha seçkin bir yer verme imkanı sunmaktadır. Temel Haklar Şartı'nun kabulü, Avrupa Birliği'nin meşruiyetini güçlendirmekte, temel hakları Birlik vatandaşları için "görünür kılmakta" ve temel hak korumasının düzeyini yükseltmektedir. Ayrıca Şart, Avrupa Birliği Anayasası yönünde atılmış önemli

1 Sart kavramı tarihte ilk defa 1215 yılında Ingiltere Kralı tarafından imzalanan "Magna Charta libertatum" da kullanılmıştır. Bu tarihe kadar "Şart" adı altında herhangi bir belge kabul edilmiş değildir. Magna Charta'dan günümüze gelinceye kadar değişik dönemlerde birçok Şart ilan edilmiştir. Ancak, bunlar içerisinde kişileri ve mülkiyeti kralın keyfi iktidarına karşı koruyan Magna Charta'nın ayrı bir yeri vardır. Bu belge iki açıdan önemlidir. †lk olarak Şart'ta yer alan 63. madde, yalnızca daha önceden özgür olanların özgürlük haklarını güvenceye almaktadır. Buna karşılık özgür olmayanları özgürleştirmemektedir. Ikinci olarak, mutlak iktidara karşı yazılı olarak teminat altına alınan savunma hakları gerçekten bir yenilik niteliğindedir. Kişisel özgürlükler yoluyla iktidarı sınrlandırma düşüncesine dayanan Magna Charta, modern anayasacılığın başlangıcını oluşturmaktadır. Yeniçağ dönemi, Şart dönemi olarak adlandırılabilir. Bu dönemde iktidarın kötüye kullanılması söz konusu olduğunda, bunun bir daha asla olmaması için yeni Şartlar ilan etme yoluna gidilmiştir. Bu kısa açıklamanın gösterdiği gibi Şart kavramı, biraz yaldızlı bir kavramdır. Şart, gelenekle ve yeni bir başlangıç yapma düşüncesiyle ilişkili olup, törensel şekilde ilan edilen, bağlayıı niteliği olmayan basit bir hukuki belgedir. Bununla birlikte kimi durumlarda Şart terimi, uluslararası yaşamı düzenleyen temel ve kurucu nitelikteki bazı çok önemli antlaşmalar için de kullanılmaktadır. Örneğin, Birleşmiş Milletler Sartı. 
bir adım teşkil etmekte (ÖHLINGER, 2000: 170) ve AB vatandaşlarının ortak kimliği açısından büyük önem taşımaktadır (PERNICE, 2000: paragraf 2).

\section{AVRUPA BIRLIĞi HUKUKUNDA TEMEL HAKLARIK KORUNMASINA GENEL BIR BAKI\$̧}

Ulusal anayasal hükümler, Avrupa İnsan Hakları Sözleşmesi, Avrupa Sosyal Sartı, İş̧ilerin Sosyal Haklarına Dair Topluluk Şartı, AB vatandaşlık hakları ve ABAD içtihatları, Avrupa Birliği'ne üye devletlerde yüksek bir temel hak koruması standardının oluşmasını sağladığı tartışmasızdır. Ancak, ulusal anayasalar ve AiHS, Birliğin hukuki işlemlerine karşı Birlik vatandaşlarına yeterli bir temel hak koruması sunamamaktadır. Çünkü, her ne kadar ulusal anayasalar ve AIHS, AB'ne üye devletler için geçerli olsa da, tüzel kişi olarak Birlik ve onun organları için geçerli değildir. Bununla birlikte, Avrupa Ínsan Hakları Sözleşmesi, bugüne kadar temel hakların Avrupa mekanunda korunması konusunda en önemli Sözleşme olmuştur. Avrupa Birliği bu Sözleşmeye katılmamakla birlikte, AB'ne üye bütün devletler AİHS'ne taraftırlar. Bu durumu dikkate alan Avrupa Birliği Adalet Divan, AB alanında temel hakların etkin bir şekilde korunmasını sağlamak üzere kararlarında AİHS'nin hükümlerine ve üye devletlerdeki ortak anayasal geleneklere dayanan bir denetim yapmaktadır (ENGELS, 2001: 1).

Temel hakların korunması konusu Avrupa Birliği hukukunda önemi giderek artan ve tartışılan bir konu olmuştur. AB Hukukunun asli (birincil) kaynaklarında ayrımcılık yasağı, temel özgürlükler ve siyasi katılım hakları yer almaktadır. Buna karşılık Antlaşmalarda kodifiye edilmiş bir temel haklar kataloğu bulunmamaktadır. Uzun bir süre bizzat Antlaşmaların kendisi Topluluk hukuku yoluyla genel ve bütünsel bir temel hak korumasunin tanınmasına yabancı kalmıştır. Bunun nedeni, insan haklarının esas olarak ekonomik ve teknik karakterli bir yapılanmayı amaçlayan Avrupa Topluluğunun başlangıçtaki öncelikleri arasında yer almamasıdır (MARCUS-HELMONS, 2001: 83; TEZCAN, 2002: 148). Ilk defa 1 Temmuz 1987'de yürürlüğe giren Avrupa Tek Senedi'nin başlangıç bölümünde temel hakların korunması konusuna yer verilmiş ve bu tanıma Maastricht ve Amsterdam Antlaşmaları (ABA m. 6) ile insan haklarına saygı göstermenin Birliğin temel ilkelerinden olduğu ifade edilmek suretiyle güçlendirilmiştir. $\mathrm{Bu}$ düzenleme Avrupa Birliği'nde temel hak koruması için en önemli dayanak noktası olmuştur. Bu düzenlemeler temel hakları korumak üzere $A B$ yasa koyucusunun inisiyatifinin bir ürünü değil, bilakis ABAD'nun temel haklarla ilgili içtihatlarının esasının Topluluk hukukunun asli kaynaklarına aktarılması niteliğindedir. $A B$ hukukunun insan hakları boyutunun oluşumunun kaynağında Topluluk Mahkemesi'nin kurucu kararları yer alır. ABAD, Antlaşmaların yorumu ve uygulanmasında kendisini AB'nin yazılı kurallarıyla 
sınırlamamıs, temel insan haklarını $A B$ hukukunun genel prensipleri içinde kabul etmiştir (ÇAVUŞOĞLU, 1999-2000: 2). Bununla birlikte, ABAD, temel hakların korunması konusunda ilk dönemde $\mathrm{AB}$ yasa koyucusu gibi çekingen bir tutum takınmıştır. ABAD, uzun süre Topluluk hukukuna özgü bir temel hak koruması geliştirememiştir. Ancak, 60'l yılların sonunda bu içtihat değişmiş ve ABAD, ulusal anayasaların standardına önemli ölçüde uygun düşen kazuistik bir temel hak korumasına yönelmiştir (POLLAK, 1991: 28-29). Bu içtihat değişikliğinin başlıca iki sebebi vardır. Birincisi, ABAD'nın 60'lı ylllarda Topluluk hukukunun üstünlüğü ve doğrudan etkisini benimsemeye başlamasıdır. Topluluk hukukunun daha fazla müdahalede bulunması, temel hak korumasının seviyesini yükseltmiştir. İkincisi, ulusal anayasa mahkemeleri içtihatlarıyla ABAD üzerinde baskı kurmuşlardır (KAKOURIS, 1990: 41). Ulusal anayasa mahkemeleri ${ }^{2}$ ABAD'ndan Avrupa kamu gücünün işlemleri alanunda da temel hak korumasinı kendisinde saklı tutmak suretiyle temel hak korumasını derinleştirmesini talep etmişlerdir (MAHLMANN, 2000: www.jurasb.de/projekte/Bibliothek/texte/Mahlmann. html).

Avrupa Birliği mekanında temel hak korumasının iyileştirilmesi ile ilgili tartışmalarda, ụ̧̈ farklı görüş ortaya atılmıştır. Birincisi, bugüne kadar uygulanan sistemin sürdürülmesidir. Buna göre, temel haklar ABAD içtihatlarıyla korunmaya devam edecektir. Bu görüşü savunanlara göre, ABAD, temel hakları koruma görevini yazılı bir temel haklar kataloğu olmadan da büyük ölçüde ve tam olarak yerine getirmiştir. Yazılı bir temel haklar kataloğu olduğunda, daha farklı bir durum ortaya çıkmayacaktır. Ayrıca bu sistemin temel hak korumasında büyük bir esneklik getirdiği de gözden uzak tutulmamahdır. Bu sistemde üye devletlerin bir uzlaşmaya varması gerekli değildir ve temel hak koruması ile ilgili ortaya çıkan yeni gelişmelerde ABAD sınırlandırılmamıs olmaktadır. 'te yandan bu sistemin benimsenmesi halinde demokratik meşruiyet sorununun ortaya çıkacağı aşikardır. Bir temel haklar kataloğu ile bağlı olmayan Adalet Divan, bir temel hak rejiminin yaratıcısı olarak Avrupa'da ortak idealler etrafında toplanan insanların üzerinde anayasa koyucu bir güç konumuna gelecektir (MAHLMANN, 2000: www.jura-sb.de/ projekte/Bibliothek/texte/Mahlmann.html).

2 Topluluk hukukunun üstünlüğü anlayışının Topluluk Mahkemesi kararlanyla şekillenmesiyle birlikte, bu üstünlügün temel hakların korunmasına ilişkin ulusal anayasal hükümler bakımından nasıl uygulanacağı sorunu ortaya çıkmıştır. Bu konuda özellikle Alman ve Italyan Anayasa Mahkemeleri, ilk dönem kararlannda, Topluluk hukuk düzeninde temel hak ve hürriyetlere ilişkin düzenlemelerin yer almaması nedeniyle kendi anayasalarının temel hakların korunmasına ilişkin hükümlerine üstünlük tanıma eğiliminde olmuşlardır. Her iki Anayasa Mahkemesi, bir temel hakkın korunmasına ilişkin anayasanın bir hükmüne aykırı olduğu ortaya çıan bütün Topluluk hükümlerinin ülkelerinde uygulanmazlı̆̆ını meydana çıkarmak için yeterli olduklarını bildirmişlerdir. Bkz. (KAKOURIS, 1990: 34-35; ÇAVUŞOČLU, 1994: $120 \mathrm{vd}$ ). 
İkinci yol, Avrupa Birliği'nin Avrupa İnsan Hakları Sözleşmesi'ne katılmasıdır. ABAD, doktrinde bu konuda yapılmış olan uzun tartışmalardan sonra Antlaşma değişikliğine gidilmeden bunun mümkün olamayacağını belirtmiştir (TEZCAN, 2002: 273 vd.). Çünkü, Antlaşmaların hiçbir hükmü açıkça veya örtülü bir şekilde Birliğe insan haklarının korunmasına ilişkin uluslararası bir sözleşmeye katılma yetkisi tanımamaktadır. Avrupa Birliği'nin AİHS'ne katılması insan haklarının korunması sisteminde esaslı ve kurumsal değişikliklere yol açacağından, bu katılıma AET Antlaşması m. 308 hükmü de izin vermemektedir. Ayrıca AlHS, yalnızca Avrupa Konseyi'ne üye olanların Sözleşmeyi imzalayabileceklerini belirtmektedir. Dolayısıyla yalnızca Avrupa devletleri Sözleşmeye taraf olabilir, devlet toplulukları taraf olamaz (MAHLMANN, 2000: www.jura-sb.de/ projekte/ Bibliothek/texte/ Mahlmann.html).

Bununla birlikte, AB'nin AİHS'ne katılmasının en basit yol olduğu da sıklıkla dile getirilen bir görüştür. Öhlinger'e göre, bu katılımın bir antlaşma değişikliğini gerektirmesi, böyle bir katılıma karşı bir argüman olarak ileri sürülemez. Çünkü, hukuki açıdan bağlayıcı bir Temel Haklar Şartı, daha ağır bir antlaşma değişikliğini gerekli kılmaktadır (ÖHLINGER, 2000: 71).

Üçüncüsü ve geriye kalan yol, bir temel haklar kataloğu oluşturmaktır. Bu yöndeki girişimler ve öneriler yeni olmayıp, eskiden beri bulunmaktadır. Bu çözüm şeklinin avantajları şunlardır: Temel haklar kataloğu, Avrupa temel hak kültürünün özünü sistemli bir şekilde bir araya getireceğinden etkili olabilecektir. ABAD içtihatlarındaki boşluklar, bilinçli bir temel haklar belgesiyle doldurulabilir. Avrupa kamu gücünün temel haklarla bağlı olmadığı alanlar kaldırılmak suretiyle bu konudaki hoşnutsuzluk giderilebilir. Bir temel haklar kataloğu ABẠD'na yazılı bir metin sunacağından, böyle bir katalog kuşkusuz hukuk güvenliğine hizmet edecektir. Ayrıca, ABAD'nun vermiş olduğu kararlar değerlendirilirken ve eleştirilirken ortada somut bir ölçüt olacaktır. Yine, temel haklar kataloğu, büyüyen Avrupa hukuk düzeninin temel normlarına Adalet Divanının hukuk yaratma gücü de dikkate alındığında daha fazla demokratik bir meşruiyet sağlayacaktır. Nihayet, temel haklar kataloğu, ileride atılacak yeni adımlarda daha da önem kazanacaktır. Zira, Temel Haklar Şartı'nın Antlaşmalara dahil edilmesinde en azından ulusal parlamentolar ABA m. 48/3'e göre Antlaşma değişikliğinin onaylanması sürecine katllacaklardır (MAHLMANN, 2000: www.jura-sb.de/projekte/Bibliothek/texte/Mahlmann. html). Hatta bu noktada Avrupa çapında yapılacak bir referandum bile tartışılmaktadır (PERNICE, 2000: 11). 


\section{KÖLN ZïRVESindeN NICE ZiRVESINE: TEMEL HAKLAR ŞARTI'NIN ORTAYA ÇIKIŞ SÜRECI}

Temel Haklar Şartı'nun ortaya çıkıs sürecini ele almadan önce, Avrupa Birliği'nin neden bir Temel Haklar Şartı'na ihtiyaç duyduğu sorusuna cevap verilmesinde fayda vardır. Ulusal, Avrupa (Avrupa Birliği) ve uluslararası hukuk alanında temel haklar -istenilen düzeyde olmasa da- etkili bir şekilde korunmasına rağmen, Temel Haklar Şartı'nı anlamlı kılan hususlar şöyle suralanabilir (ENGELS, 2001: 6; HIRSCH, 1999: paragraf 24-32):

Ilk olarak, hukuk devleti ilkesi, topluma, herkes tarafından ulaşılabilir ve anlaşılabilir bir temel haklar listesi sunması gerekir. Her ne kadar Avrupa Birliğinde Adalet Divanı tarafından yargıç yapımı hukuk yoluyla geliştirilen bir temel haklar rejimi bulunsa da, bunun uzmanlar tarafından bile bilinmesi mümkün değildir. Temel hakları topluca gösteren, kodifiye edilmiş bir temel haklar kataloğu açıklık şartının bir gereğidir.

İkinci olarak, her ne kadar Avrupa Birliği Adalet Divan sürekli olarak somut olaylarda etkili bir temel hak içtihadı ortaya koysa da, Divanun bu olaylarda birincil mi yoksa ikincil kaynaklara mı dayandığı belli değildir. Büyük ölçüde Avrupa Birliği'nin öncülüğünde hazırlanan ve üye devletlerde doğrudan geçerli olan yasama işlemleri, temel haklar ölçü alınarak denetlenmelidir.

Üçüncü olarak, temel haklar kataloğu Topluluğun meşruiyetini güçlendirecektir. İçtihat yoluyla güvence altına alınan temel haklar, Şart\%ı\$n ilanıyla "görünür" hale gelecek ve Topluluk karar organlarının işlemlerinin kabulü artacaktır. Şart aynı zamanda Topluluk içerisindeki siyasi iradenin oluşumu sürecini yönlendirecek ve kamuoyuna Topluluğun demokratik yapıya sahip olduğu açıklanmış olacaktır.

Ayrıca, bir temel haklar kataloğunun uzlaşma sağlayıcı bir fonksiyona sahip olduğu gözden uzak tutulmamalıdır. Temel haklar yalnızca siyasi iktidara karşı ileri sürülen savunma haklarını değil, aynı zamanda objektif bir değer düzenini de ifade ederler. Temel Haklar Şartı, Avrupa Birliğinin temel değerleri üzerinde vatandaşlar arasında ortak bir konsensüsün oluşmasında önemli bir payı olacaktır.

Yine, ulusal temel hak katalogları bireyleri Avrupa Birliğinin tedbirlerine karşı yalnızca zorunlu hallerde korumaktadır. Avrupa Birliği Adalet Divanı karşılaştırmalı hukuk yoluyla daima ulusal anayasalara da dayanmakla birlikte, ulusal anayasalar ayn şekilde Avrupa Birliği için geçerli değildir.

Nihayet, her ne kadar Avrupa İnsan Hakları Sözleşmesi, Avrupa Birliği Adalet Divanı kararlarında yer alsa da, Sözleşme Birlik açısından tam olarak geçerli değildir. Ayrıca, AİHS, Avrupa Birliğinin şu anki bütünleşme sürecinde etkili bir temel hak koruması için zorunlu olan bütün hakları da içermemektedir. 
AlHS, birkaç istisna hariç ekonomik ve sosyal haklara ve Birlik vatandaşlğ̆ ile ilişkili haklara yer vermemektedir.

Torsten Stein, Avrupa Birliği'nin iki sebepten ötürü bir Temel Haklar Şartı'na ihtiyacı olduğunu belirtmektedir. Yazara göre ilk sebep, şu anda geçerli olan sistemin çok fazla anomaliler göstermesi, ikincisi ise, gerçekte ABAD tarafından sağlanan korumanın tatmin edici olmaktan uzak oluşudur. Ortaya çıkan anomalilerden ilki, ABAD'nın her bir olayda, daha sonra başvurulacak olan temel hak yorumu yapması veya "icat" etmesidir. ABAD'nun içtihat yoluyla boşluk doldurması, ulusal hukuk sistemlerinin yabancı olmadığı bir yöntemdir. Ancak, ABAD, temel hakları korurken, herhangi bir hukuki metin ile bağlı değildir. Her ne kadar ABAD, temel hakları korurken üye devletlerdeki ortak anayasal geleneklere ve AİHS'ne başvursa da, bunlar ABAD'n bağlayıcı nitelikte değildir. Diğer bir anomali, Topluluk kural koyucularının düzeltici etkilerinin olmamasıdır. Yazara göre, ABAD, geçmişte temel hakların koruyucusu olmaktan çok, entegrasyonun itici gücü olarak hareket ettiğinden, temel hak koruması tatmin edici düzeyde değildir (STEIN, 2001: 94-95).

Temel Haklar Şartı'nn kabul edilmesi yönündeki özel ve kamusal ön hazırlıklar bir tarafa bırakılacak olursa, Temel Haklar Şartı'nun kabulü yönündeki çaba 1999 yllında başlamıştır. 1999 yllının başında dönem başkanlığını devralan Almanya Temel Haklar Şartı projesine özel önem vermiş ve Şart'in kabul edilmesini öncelikli hedefler arasına koymuştur. 1999 yllının Haziran ayında yapılan Köln zirvesinin sonuç bildirgesinde şöyle denilmektedir: "Avrupa Konseyi, Avrupa Birliğinin şu andaki gelişiminde Birlik alanında geçerli olan temel hakların bir Şart'ta toplanması ve böylece görünür kılınabilmesi görüşünü taşımaktadır". Köln zirvesinde ayrıca, Şart'ın özgürlük, eşitlik ve yargısal hakları, Birlik vatandaşlığına bağlı haklar ile ekonomik ve sosyal hakları içereceği; ekonomik ve sosyal hakların program hükümler olarak düzenlenmemesi kararlaştırılmıştır. Böylece daha Köln zirvesinde AİHS'nde yer alan hakların oluşturulacak Şart için yeterli olmayacağı kabul edilmiştir. Zira, AïHS, sosyal haklar ile Birlik vatandaşığına bağlı hakları içermemektedir.

Temel Haklar Şartı'nda yer alacak hakların belirlenmesinde hangi kaynaklardan yararlanılacağ anayasal gelenekler, Avrupa Sosyal Şartı ve İşçlerin Sosyal Haklarına Dair Topluluk Şartı olarak tespit edilmiştir. Bu dört kaynağın gösterilmesiyle Avrupa Birliği Antlaşması'nın 6. maddesinin ikinci fikrasında yer alan düzenlemenin kapsamı genişletilmiş olmaktadır. Bu düzenlemede yalnızca ortak anayasal gelenekler, AİHS ve topluluk hukukunun genel ilkeleri yer almaktaydı. Avrupa Birliğine üye devletlerin çoğunluğunda iktidarda bulunan sosyal demokrat hükümetler, Şart'ta sosyal haklara da yer verilmesini istemişlerdir. 
Şart'in hukuki bağlayıcılığı sorunu konusunda Köln'de şöyle bir uzlaşmaya varılmıştır: Şart'ın antlaşmalara dahil edilip edilmeyeceği veya ne şekilde dahil edileceği, Şart metñinin 2000 yılının Aralık ayında törensel şekilde ilan edilmesinden sonra kararlaştırılacaktır.

15-16 Ekim 1999 tarihinde yapılan Tampere zirvesinde Şart ile ilgili konularda bazı önemli kararlar alınmıştır. Öncelikle Şart metnini hazırlayacak olan bir kurulun oluşturulmasına karar verilmiştir. Ayrica, kurulun hazırlayacağı metnin bir tasarı olacağı kabul edilmiştir. Yine Kurul başkanlı̆̆ı, kurul tarafından hazırlanan Şart taslağının herkes için kabul edilebilir nitelikte olmasını sağlayacak ve ayrıca tasarı, diğer hazırlık işlemleri konusunda Avrupa Konseyini yönlendirecektir.

Konvansiyon, Tampere karanndan iki ay sonra, 17 Aralık 1999 tarihinde Brüksel'de çalışmalarına başlamıştır. Eski Federal Alman Cumhurbaşkanı ve eski Federal Anayasa Mahkemesi başkanı olan ve Federal Alman hükümeti tarafından kurula atanan Roman Herzog, Kurul tarafindan başkan seçilmiştir. Konvansiyon başkanlığı, başkan Roman Herzog, ulusal parlamenterler temsilcisi Gunnar Jansson, Avrupa Parlamentosu temsilcisi Inigo Mendez de Vigo ve Komisyon temsilcisi Antonio Vitorino'dan oluşmuştur. I Şubat 2000 tarihli ikinci oturumunda Kurul, kendisine Konvansiyon ismini vermiştir. Konvansiyon, 18 oturum sonucunda 2 Ekim 2000 tarihinde hazurlanan Şart metnini kabul ederek çalışmaların tamamlamıştır. Böylece Konvansiyon, kendisine verilen görevi süresinde tamamlamış ve Temel Haklar Şartı Taslağı devlet ve hükümet başkanlarından oluşan Avrupa Konseyi'nin 13-14 Ekim 2000 tarihli Biarritz toplantısında ele alınmış ve kabul edilmiştir. Tasarının Köln bildirgesine uygun olarak üzerinde hiçbir değişiklik yapılmaksızın 7 Aralık 2000 tarihinde Nice zirvesinde Avrupa Parlamentosu, Konsey ve Komisyon tarafindan törenle ilan edilmesi kararlaştırılmıştır. Böylece Şart, hukuki bağlayıchlığa sahip olmayan, ancak önemli bir siyasi belge niteliğine sahip olmuştur.

\section{A. Şart'ın Hazırlanmasında İzlenen Yöntem}

\section{Konvansiyon}

Bir Temel Haklar Şartı tasarısı hazırlamak AB'nin olağan işlemlerinden olmadığından, Devlet ve hükümet başkanları, AB için hangi temel hak ve hürriyetlerin geçerli olacağını belirlemek üzere bir kurul oluşturmuştur. Temel Haklar Sartı'nı hazırlayacak olan Kurul oluşturulurken şimdiye kadar görülmemiş ve oldukça değişik bir yöntem benimsenmiştir. Avrupa Birliği çerçevesinde ilk kez Avrupa Parlamentosu ve ulusal parlamento temsilcilerinden oluşan sui generis bir organa bir temel haklar kataloğu hazırlama görevi verilmiştir. 
Tampere kararına uygun olarak Şart'ı hazırlayacak olan Konvansiyon 62 üyeden oluşmaktadır. Üyeler, dört gruptan oluşmaktadır: Ulusal parlamentolar ve Avrupa parlamentosu üyeleri, devlet ve hükümet başkanları ile $A B$ Komisyonu tarafından atanan üyeler. ABAD'ndan 2 temsilci ve 1'i AItHM'nden olmak üzere Avrupa Konseyi'nden 2 temsilci gözlemci olarak katılmıştır.

Konvansiyonun Oluşumu

\begin{tabular}{|l|c|c|}
\hline & Sayı ile & yüzde ile \\
\hline Ulusal parlamento üyeleri* $^{*}$ & 30 & 48 \\
\hline Avrupa parlamenterleri & 16 & 26 \\
\hline Devlet ve hükümet başkanlarınca atanan üyeler** & 15 & 24 \\
\hline AB Komisyonu tarafından atanan üyeler & 1 & 2 \\
\hline Toplam & 62 & 100 \\
\hline
\end{tabular}

* Her üye devlete iki temsilci. Iki meclise sahip devletlere böylece her meclisten bir temsilci gönderme imkanı tanınmıştır.

* Her üye devlete bir temsilci

Temel Haklar Şartı'n hazırlayacak Konvansiyonun üyelerinin tamamına bakıldığında dörtte üçünün parlamenterlerden oluştuğu görülmektedir. Hazırlanacak olan belgenin önemi dikkate alındığında böyle bir oluşum, AB tarihinde bir yeniliktir.

\section{Konvansiyonun Çalışma Şekli}

Konvansiyon, ilk defa 1999 yılının Aralık ayında toplanmış ve çalışmalarını Tettinger'in esprili bir şekilde belirttiği gibi, bir bebeğin doğumu için gerekli olan 9 ay gibi kısa bir sürede tamamlamıştur (TETTINGER, 2001: 1011). Konvansiyon, Şart tasarısını tamamlayıncaya kadar Brüksel'de toplam 18 oturum yapmıştır. Kamuya açık olarak yapılan oturumlar kural olarak bir buçuk gün olarak tayin edilmiştir. Bununla birlikte görüşmelerin yoğunlaştığı dönemlerde sayısız informel konuşmalara izin verilmiş ve oturumlar üç güne kadar uzamıştır. Her formel oturumdan önce üç "büyük grup" (hükümet temsilcileri, Avrupa parlamenterleri ve ulusal parlamenterler) kendi aralarinda toplanmışlar ve grupların başkanları başkanlık çalışmalarının durumu hakkında grupları bilgilendirmişlerdir.

Avrupa parlamenterleri birbirlerini daha önceden parlamento çalışmalarından tanımalarından dolayı tam anlamıla homojen bir grup oluşturmuşlardır. Buna karşılık hükümet temsilcileri ve ulusal parlamenterler 
Genel olarak değerlendirildiğinde katılım ilkesinin büyük ölçüde gerçekleştiği söylenebilir. Özellikle de devlet ve hükümet başkanları zirvelerinde yürütülèn usuller ile mukayese edildiğinde bu husus daha açk bir sekilde görülmektedir.

\section{TEMEL HAKLAR ŞARTI'NIN AMACI VE ÖNEMI}

Temel Haklar Şartinın amacı, AB kurumlarının insan häklarına saygı duymasını sağlamak, temel hakları güvence altina almak suretiyle etkin bir şekilde korumaktır. Bir başka deyişle, Avrupa Birliği'nin yetkilerinin temel haklar lehine sınırlandırilması amaçlanmaktadır. Temel Haklar Şartı ile ulaşılmak istenen amaçlardan biri de, Avrupa Birliği'nin demok'ratik meşruiyet noktasındaki eksikliklerinin giderilmesidir.

- Avrupa Birliği Konseyi, Köln zirvesinde, Temel Haklar Şartı'nın amacın temel hakların üstün önemini ve Birlik vatandaşları için etkisini "görünür kılabilmek" şeklinde ifade etmiştir (ODER, 2000:486). Dolayısıyla Konvansiyona yeni bir şey yaratma veya yenileştirme değil, aksine var olanları açığa çıkarmak ve sistematik bir şekilde toplamak görevi verilmiş olmaktadır (KOMISYON, 2000: paragraf 7).

Avrupa Birliği Komisyonunun görüşüne göre, Avrupa Birliği siyasi alanda yeni bir bütünleşme sürecine girdiğinden, bir :Temel Haklar Şartı zorunludur. Şart, özgürlük, güvenlik ve hukuk alanunda bütünleşmiş bir siyasi Avrupa'nın en önemli kilometre taşlarından birisi olacaktır. Şart, siyasi ve ahlaki meşruiyetin vazgeçilmez bir aracı konumundadir. Sart, Avrupa demokratik toplumun ortak değerlerini ifade etmektedir (KOMISYON, 2000: paragraf 8).

Komisyona göre Temel Haklar Şartı; pratik ve ideal amaçları en iyi şekilde uyumlulaştırmıştır. Pratik deyimiyle kastedilen husus, "ne pahasına olursa olsun" yeni bir şey yaratma çabasına girilmemesi, aksine Köln zirvesinde belirlenen çerçevenin dikkate alınmasıdır. Buna karşlık ideal amaçlar da güdülmüştür: İlk olarak, kodifiye- çalışmalarında farklı kaynaklardan yararlanılmıstır. Özellikle AlHS, ortak anayasal gelenekler, Avrupa Sosyal Şartı, İş̧ilerin Sosyal Haklarına Dair Topluluk Şartı, Topluluk hukukunun birincil ve ikincil kaynakları, çeşitli uluslararası antlaşmalar, ABAD ve AİHM'nin içtihatları dikkate alınmıştır. İkinci olarak, Şart metninde klasik medeni ve siyasi haklar yanında Birlik vatandaşlı̆̆ı hakları ile sosyal ve ekonomik haklara da yer verilmiştir. Nihayet, bazı "yeni haklar" Şart metninde yer almıştır. Bu haklar daha önceden de bulunmaktaydı, ancak bunlar bugüne kadar belli ölçüde koruma görmekle birlikte açıkça temel hak olarak geçerli değildi. Bu bağlamda örneğin kişisel bilgilerin korunması, biyoetik ile ilgili temel ilkeler ve iyi idare hakkı, Sartta yer alan yeni haklardandır. Temel Haklar Şartı, temel hakları "görünür kılmak" dışında, aynı zamanda hukuk güvenliğine de önemli bir katkı 
sağlamaktadır. Böylelikle Birlik düzeyindeki temel hak koruması iyileştirilmektedir (KOMISYON, 2000: paragraf 9-10).

\section{TEMEL HAKLAR ŞARTI'NIN IÇERiĞi}

Şartta toplam 54 madde yer almakta ve bir başlangıç ve yedi bölümden oluşmaktadır. Birinci bölüm "insan onuru" (m. 1-5), ikinci bölüm "özgürlükler" (m. 6-19), üçüncü bölüm "eşitlik" (m. 20-26), dördüncü bölüm "dayanışma" (m. 27-38), beşinci bölüm "vatandaşlık haklarn" (m. 39-46), altına bölüm "yargısal haklar" (m. 47-50) ve son olarak yedinci bölüm "genel hükümler" (m. 51-54) başlığını taşımaktadır.

Şart, öncelikle Köln zirvesinde alınan kararlara uygun olarak AïHS, Avrupa Sosyal Şartı, İşçilerin Sosyal Haklarına Dair Topluluk Şartı ve üye devletlerdcki ortak anayasal gelenekler vs. dikkate alınarak hazırlanmıştur. Nitekim bu husus Şart'ın başlangı̨̧ bölümünde belirtilmiştir: "Bu Bildirge, Topluluk ve Birliğin yetkileri ve görevlerini ve yetki ikamesi ilkesini dikkate alarak özellikle Üye Devletlerin ortak uluslararası yükümlülükleri ve anayasal gelenekleri, Avrupa Birliği Antlaşması, Topluluk Antlaşmaları, Avrupa İnsan Hakları ve Temel Hak ve Özgürlüklerin Korunması Sözleşmesi, Topluluk ve Avrupa Konseyi tarafından kabul edilen Sosyal Bildirgeler ve Avrupa Toplulukları Adalet Divanı ve Avrupa İnsan Hakları Mahkemesi'nin içtihat hukukundan kaynaklanan hakları yeniden teyid etmektedir." Bunlar içerisinde özellikle AlHS'den daha çok yararlanılmıştır. Bu noktada, Şart'ın yorumlanmasında AİHM'nin içtihatlarının özel bir öneme sahip olacağı söylenebilir.

Şart metni büyük ölçüde mevcut hukuki metinler esas alınarak hazırlanmıştır. Bundan dolayı Şart, devrimci nitelikte yeni bir kodifikasyon değil, bilakis esas olarak ulusal, ulusalüstü ve uluslararası alanda zaten var olan hakların derlenip, sistematik bir şekilde düzenlenmesi niteliğindedir.

Şart'ta yer alan birçok madde AB'ne üye devletlerin anayasalarından alınmakla birlikte, bazı maddelerin karşılıkları üye devletlerin anayasalarının birçoğunda bulunmamaktadır. Şartın 1. maddesi, Alman Anayasası'nın 1. maddesindeki düzenlemeye benzer şekilde formüle edilmiştir. Askerlik görevini yapmayı reddetme hakkı (m. 10/2), sanat ve bilim hürriyeti (m. 13) düzenlenirken Alman Anayasası vaftiz babahı̆g yapmıştır.

\section{A. Klasik Koruyucu Haklar, Savunma Hakları ve Katılım Hakları}

Temel Haklar Şart1, Federal Alman Anayasası'nda olduğu gibi, insan onuru güvencesi ile başlamaktadır (m. 1). Yaşam hakkı (m. 2/1), kişinin bedensel ve ruhsal dokunulmazlığ genel olarak güvence altına alınmış (m. 3/1) ve $A B$ 'nin bugüne kadar ceza normu koyma konusunda bir yetkiye sahip 
olmamasına rağmen ölüm cezası yasağı (m. 2/2) ve işkence yasağı (m. 4) gibi diğer bazı yasaklar öngörülmüştür. Ayrıca, kölelik, zorla çalıştırılma ve insan ticareti yasağı da düzenlenmiştir (m. 5).

Kişi özgürlüğü ve güvenliği hakkı, Şart'in 6. maddesinde düzenlenmiştir. Bu hak, ABA'nın VI. Bölümünde yer alan suçlulukla mücadele ve ceza hukuku uyumlulaştırılması alanında uyumlulaştırma tedbirlerinin geçerliliğinin ölçütü olarak somut öneme haiz olacaktr (MAHLMANN, 2000: www.jura-sb.de/ projekte/Bibliothek/texte/Mahlmann.html). Şart, diğer önemli klasik özgürlük haklarını da formüle etmiştir: Özel ve aile yaşamına, konutuna ve haberleşmesine saygı gösterilmesini isteme hakkı (m. 7), düşünce, vicdan ve din özgürlüğü (m. 10), ifade ve haber alma özgürlüğü (m. 11), toplanma ve örgütlenme özgürlüğü (m. 12), sanat ve bilim özgürlüğü (m. 13), eğitim kurumları tesis ctme özgürlüğü (m. 14/3), çalışma özgürlüğü (m. 15/1).

Evlenme ve aile kurma hakkı (m. 9), ulusal mevzuata gönderme yapılmak suretiyle düzenlenmiştir. Formülasyon, AïHS'nin 12. maddesine dayanmakta, ancak kadın ve erkek ilişkisine dayanacağ 1 açıkça öngörülmemektedir. Böylece ulusal yasa koyuculara aile kurma ve birlikte yaşam için çerçeve olarak evlenmeden daha farklı usulleri tanıma imkanı verilmiştir. Mülkiyet ve miras hakkı ( $m$. 17) ile ticari faaliyette bulunma özgürlüğü $(m$. 16) güvence altma alınmıştır. Sığınma hakkının düzenlendiği 18. maddede, bu hakkın 28 Temmuz 1951 tarihli Cenevre Sözleşmesi ve sığınmacıların statüsüne ilişkin 31 Ocak 1967 tarihli Protokol kuralları dikkate ahnarak ve Avrupa Toplulugunu kuran Antlaşma'ya uygun olarak teminat altına alınması gerektiği belirtilmiştir. Bunların dışında, toplu sınır dışı etmeye karşı bir koruma öngörülmüş, hangi hallerde iade yasağının uygulanacağı düzenlenmiştir (m. 19).

Şart metninde genel eşitlik ilkesi (m. 20) yanında ayrımcllık yasağına da (m. 21) yer verilmiştir. Ayrımcilık yasağı ile ilgili bu madde, ATA m. 13, AİHS $\mathrm{m}$. 14 ve Biyo-tıp Sözleşmesi $\mathrm{m}$. 11 hükümilerinden yararlanılarak formüle edilmiştir. Madde hükmüne göre, cinsiyet, ırk, renk, etnik veya sosyal köken, kalıtımsal özellikler, dil, din veya inanç, siyasi veya başka herhangi bir görüş, bir ulusal azınlığın üyesi olma, hususiyet, doğum, maluliyet, yaş veya cinsel eğilim gibi herhangi bir nedenle ayrımcllk yapılması yasaktır. Görüldüğü gibi, madde metninde ayrımcılığa yol açabilecek nedenler olabildiğince geniş şekilde sayılmıştır. Ayrıca bu sayımın sınırlı olmadığı da açıkça belirtilmiştir. Bir ulusal azınlığın üyesi olma nedeniyle ayrımclığa uğramama dışında ulusal azınlıkları koruyucu bir başka düzenleme daha öngörülmüştür. Şartın 22. maddesinde yer alan bu düzcnlemeye göre, Birlik, kültürel, dini ve dilsel çeşitliliğe saygı gösterecektir. Şart ayrıca kadın ve erkek arasındaki eşitliği güvence altına almakta ve ycterli şekilde temsil edilmeyen cinsin lehine belirli avantajlar sağlamak surctiyle olumlu ayrımcilık imkanını kabul etmektedir (m. 23). Bu 
düzenleme, ATA m. 141'de yer alan güvenceden daha fazla bir güvence getirmediğinden normatif bir yenileştirme sayllmaz. ATA m. 12'de yer alan uyrukluk nedeniyle ayrımcıllk yasağı, AB vatandaşları için Şartın 21. maddesinin ikinci fikrasında düzenlenmiştir. Avrupa Birliğine üye devletlerde hukuka uygun şekilde ikamet eden ve çalışma izni almış olan üçüncü devletlerin vatandaşları, Birlik vatandaşlarının çalı̧̧ma şartlarına eşit çalışma şartlarından yararlanma hakkına sahiptir (m. 15/3).

Siyasi katılma hakları ile ilgili olarak Avrupa Parlamentosu seçimlerinde oy kullanma ve aday olma hakkı $(\mathrm{m}$. 39) ve yerel seçimlerde oy kullanma ve aday olma hakkı (m. 40), ATA m. 19 ve m. 190/1'deki mevcut hukuki duruma uygun düşecek şekilde düzenlenmiştir. Siyasi iradenin oluşumunda partilerin rolü, ATA m. 191'de olduğu gibi, açıkça zikredilmiştir (m. 12/2).

Bunların dışında Şart metninde iyi idare hakkı (m. 41), kamu denetçisine başvurma hakkı (m. 43) ve dilckçe hakkı (m. 44) güvence altına alınmıştır. Şartın 41. maddesinin 3. flkrasinda ATA m. 288'deki düzenlemeye uygun olarak Topluluğun sorumluluğuna ilişkin bir düzenleme yer almaktadır. Birlik vatandaşlarına ve bir üye devlette ikamet eden bütün gerçek ve tüzel kişilere, ATA m. 255'deki mevcut düzenlemeye uygun olarak, Avrupa Parlamentosu, Konsey ve Komisyon belgelerine erişme hakkı tanınmıştır (m. 42).

Şart, hukuk devleti ilkesinin bir gereği olarak usuli güvencelere ayrıntılı bir şekilde yer vermiştir. Bu haklar, etkili bir hukuki yola başvurma hakkı ve adil yargılanma hakkından savunma haklarına ve adli yardımdan yararlanma hakkına ( $\mathrm{m} .47)$, masumiyet karinesinden (m. 48) geçmişe etkili olma yasağı (m. 49) veya yeniden yarglanma yasağına ( $m$. 50$)$ kadar uzanmaktadır.

\section{B. Sosyal Haklar}

Tenel Haklar Şartı ile ilgili hazırlık çalı̧̧malarında en fazla tartışlan konulardan biri de, ekonomik ve sosyal haklar konusudur. Böyle bir tartışmanun ortaya çımasını normal karşılamak gerekir. Zira, sosyal haklar ile ilgili anlaşmazlık, insan hakları tartışmaları kadar eskidir. Temel Haklar Şartı'nın hazırlık sürecinde $A B$ 'nin sosyal hakların yaşama geçirilmesi için olumlu edimde bulunma yetkisinin bulunmadığı argümanı ileri sürülerek, sosyal hakların kabulü genel olarak engellenmeye çalışılmıştır. Sosyal hakların Şart'a alınmasına karşı çkanlar temelde iki argüman ileri sürmüşlerdir:

1. Sosyal haklar "gerçek haklar" değildir, daha çok program hükümlerdir ve çoğu zaman yerine getirilmeyen vaatler olarak kaldığından vatandaşlarda memnuniyetsizliğe yol açmaktadır.

2. Sosyal hakların gerçekleştirilmesi için mali kaynaklara ihtiyaç vardır. Mali kaynaklar nihayetinde politik faaliyet alanın aşmakta ve uygulamada 
mahkemeler ekonomik sorunlar hakkında karar vermeye zorlanmaktadır (ENGELS, 2002: www.fian.de/foodfirst/food003.htm).

Buna karşılık Konvansiyonda bu argümanların yanlıs olduğu ve çoktan çürütüldüğü görüşü ağır basmıştır. Bir başka deyişle, siyasi ve sosyal haklar arasında önemli bir farkın bulunmadığına işaret edilmiştir. Bu anlayışa göre, siyasi veya sosyal hak olsun, bütün haklar, devletin yerine getirmesi gereken üç yükümlülük içerir: saygı gösterme, koruma ve olumlu edimde bulunma yükümlülüğ̈ü (ENGELS, 2001: 12).

Temel Haklar Şartı, sosyal haklar olarak nitelenen hakların büyük çoğunluğuna yor vermiştir. Bununla birlikte Şart'ta yer alan bütün haklar düzenlenirken saygı gösterme ve koruma alanlarına dikkat edilmiştir. Sosyal haklar düzenlenirken birçok yerde "güvence altına alınmıştır" ifadesi kullanılmamış, bunun yerine "tanıma" ve "saygı gösterme" deyimleri kullanılmıştır. Yine, sosyal haklarla ilgili düzenlemelerde ulusal devletlerin yetkisine göndermede bulunulmuştur.

Sosyal haklar düzenlenirken bu hakların özel bir bölüm altında mı, yoksa bir kısmının özel bir bölümde, diğerlerinin ise Şart'ın tamamına serpiştirilmek suretiyle mi düzenleneceği konusu üzerinde tartışma çkmıştır. Sonuçta, sonuncu yöntem benimsenmiş ve sosyal hakların çoğunluğu "dayanışma" başlığını taşıyan 4. bölümde, bazı sosyal haklar ise diğer bölümlerde düzenlenmiştir. Toplam 12 maddeden oluşan 4. bölümde surasıyla şu konulara yer verilmiştir: İş̧ilerin işletme içinde bilgi alma ve danısma hakkı (m. 27), toplu sözleşme görüşmeleri yapma ve eylem hakkı (m. 28), işe yerleştirme hizmetlerinden yararlanma hakkı (m. 29), haksız işten çlkarmaya karşı koruma (m. 30), adil ve hakkaniyete uygun çalışma koşulları (m. 31), çocuk işçi çalıştırmanın yasaklanması ve çalışan gençlerin korunması (m. 32), aile ve meslek yaşamı (m. 33), sosyal güvenlik ve sosyal yardım (m. 34), sağlık hizmetleri (m. 35), genel ckonomik konulardaki hizmetlerden yararlanma (m. 36), çevrenin korunması (m. 37) ve tüketicinin korunması (m. 38).

\section{Modern Insan Hakları Belgesi Olarak Şart}

Şart'ın hazırlık sürecinde yapılan tartışmalar, sözlü görüş almalar ve yazılı talepler çerçevesinde sürekli olarak Şartın modern toplumda temel hak korumasının gerektirdiği hususları içermesi ve kabul edilecek metnin modern bir temel haklar kataloğu olması gerektiği dile getirilmiştir. Hazırlanacak olan metinde biyo-teknoloji, kişisel bilgilerin korunması, çevrenin korunması gibi alanlarda özel düzenlemelerin yapılması talep edilmiş ve nihai metinde bu haklar yer almıştır. 
Temel Haklar Şartı, günümüzdeki uluslararası insan hakları belgeleri içinde en modern temel hak kataloğu olarak nitelenebilir. Şartın bu özelliği, onun bir taraftan yasa yapımı alanındaki aktüel gelişmeleri dikkate alan, en son hazırlanmıs metin olmasından gelmektedir. Diğer taraftan kapsamlı bir temel haklar kataloğu hazırlama kararı, "modern temel haklar"ın Şart metnine girmesini sağlamıştır. Gerçekten Şart, açıkça modern temel hakları içermektedir: Vücut dokunulmazlığı hakkının biyo-teknoloji alanını da kapsayacak şekilde düzenlenmesi (örneğin, insanların kopyalama yoluyla üretilmesinin yasaklanması); Kişisel bilgilerin korunması; Ayrımalık yasağın düzenleyen maddede, var olan özellikler dışında kalıtımsal özelliklerden, bir azınlığa mensup olmaktan, maluliyet, yaş veya cinsel eğilimden dolayı ayrımcılık yasağı getirilmiştir; Kadın ve erkek arasındaki "basit" ayrımolık yasağını aşan, daha kapsamlı bir eşitlik maddesinin öngörülmesi; Çocukların hakları; Yaşlıların hakları; Engellilerin toplumla bütünleştirilmesi; Aile ve meslek yaşamının bağdaştırılması gereğinin öngörülmesi; Genel ekonomik konulardaki hizmetlerden yararlanma; Çevrenin ve tüketicinin korunmasına ilişkin program hükümler; İyi idare hakkı ve Avrupa Parlamentosu, Konsey ve Komisyon belgelerine crişme hakkı.

Eski temel hak kataloglarında söz konusu modern haklar ancak yargıcin hukuk yaratmasi yoluyla geliştirilebilmekteydi. Şartta, ekonomik ve sosyal haklar ile kişisel ve siyasal haklar aynı haklara malik olmayı içerecek şekilde düzenlenmiştir. Böylece bölünmezlik postulatı ve insan haklarının karşılıklı birbirlerini zorunlu kılması açıkça onaylanmıştır.

\section{TEMEL HAKLAR ŞARTI AVRUPA BiRLIĞínde YETKILERIN GENIŞLEMESINE YOL AÇIYOR MU?}

Temel Haklar Şartı ile ilgili çalışmaların başlangıcında bu sorun tartışlmış, hatta Konvansiyon oturumları boyunca hep gündemde kalmıştır. Bir temel haklar kataloğu formüle edilirken, yalnuzca AB'nin kendine özgü yetkilerine yönelen bir katalog mu, yoksa temel hakların tümünü kapsayan tam bir temel haklar kataloğu mu olmalıdır?

Gerçi devlet ve hükümet başkanlan, Köln kararında özgürlük haklarından, ekonomik ve sosyal haklardan ve birlik vatandaşlığı haklarından oluşan kapsamlı bir katalog olması gerektiğini beyan etmişlerdir. Ancak, Köln kararında aynı zamanda Birlik alanında geçerli olacak temel hakların bir Şart'ta toplanması ve böylece temel hakların görünür kılınması gerektiği de ifade edilmiştir. Buna dayanılarak dar kapsamlı bir Şart olması gerektiği ileri sürülcbilir. Bu noktada Köln kararı açık ve kesin değildir. Uzun tartışmalardan sonra Konvansiyon, temel hakları kapsamlı bir şekilde içeren bir kataloğun 
hazırlanmasında mutabık kalmıştır. Burada etkili olan başlıca üç sebep vardır (ENGELS, 2001: 10-11):

1. Sınırlı bir temel hak kataloğu zararlı olabilir. Zira, öncelikle eksik bir Şart'ın uluslararası alandaki yansıması uluslararası insan hakları rejiminden geri adım olarak yorumlanacaktır. Örneğin, idam cezası yasağının AB'nin düzenleme alanına girmediği herkes tarafından kabul edilen bir husustur. Bununla birlikte kuşkusuz bu temel hakkın düzenlenmemesi uluslararası alanda tahripkar bir işaret olacaktır. Bu, AB'nin idam cezasının kaldırılması yönündeki uluslararası girişimleri dikkate alındığında daha iyi anlaşılır.

2. Birlik yetkilerinin selcktif bir şekilde sınurlanması mümkün değildir. Örneğin, Alman cyaletleri ilk önceleri eğitim hakkının Şart'a alınmaması konusunda ısrar etmişlerdir. Cuünkü eğitim politikası (en azından Almanya'da) eyaletlerin meselesidir. Ancak, AT Antlaşması m. 149 açıkça eğitim politikası ile ilgili alanlarda Birliğin yetkileri bulunduğunu söylemektedir.

3. Bir temē hak kataloğu uzun bir dönem için kaleme alını. Birlik içerisindeki her yetki değişikliğinden sonra Şart'ın yeniden ele alınması ve yeni yetki düzenine uydurulmak zorunda kalınmasından kaçınılmalıdır.

Komisyon'un da belirttiği gibi, Temel Haklar Şart'nın Birliğin ve Topluluğun Antlaşmalarda gösterilmiş olan yetkilerini genişletici veya daraltıcı bir etkisi yoktur. Temel Haklar Şartı'n hazırlayan Konvansiyona bu konuda herhangi bir yetki verilmiş değildir. Antlaşmalarda değişiklik yapma yetkisi hükümet zirvelerinde kararlaştırılan bir konu olarak kalmıştır. Konvansiyon çalışmalarında tartışılan bir başka husus da, Şart'ın üye devletlerin anayasalarında bir değişiklik yapılmasını zorunlu kılıp kılmayacağı konusudur. Bu konuda Temel Haklar Şartı'nı üye devletleri anayasaların değiştirme yükümlülüğü altına sokmadığ1 şeklinde bir sonuca ulaşılmıştır. Şart, üye devletlerde insan haklarına saygı konusunda üye devletlerin anayasalarının yerine geçmemektedir. Yine Temcl Haklar Şartı, Antlaşmalarda öngörülmüş olan hukuki başvuru yolları ve yargısal yapılanma konusunda herhangi bir değişikliğe yol açmamaktadır (KOMiSYON, 2000: Paragraf 14).

Şart'in AB'nin yetkilerini genişlettiği yolundaki endişeleri bertaraf etmek için, Şart metrine bir "genel hüküm" konulmuştur. Bu hüküm kimin Şart ile bağlı olduğunu açıķa düzenlemektedir: Madde 51 hükmüne göre, Şart hükümleri, yetki ikamesi ilkesi (subsidiarite) dikkate alınarak Birliğin kurumları ve organlarına ve Birlik hukukunu uyguladıklarında üye devletlere yöneliktir. Bu durumu daha da güçlendirmek için aynı maddenin ikinci fıkrasında, Şart'ın Birlik için yeni yetkiler ve görevler tesis etmediği ifade edilmiştir. 


\section{VI. ŞART'A YÖNELTILEN ELEŞTiRiLER}

Şart'in hazırlı sürccinin tamamı farklı siyasi gruplar tarafından bazı açılardan şiddetli bir şekilde eleştirilmiştir. Şart'a yöneltilen en temel eleştiri, Avrupa Birliği'ne özgü bir Temel Haklar Şartına gerek olmadığı, Birliğin AİHS'ne katılmasının yeterli olacă̆ şeklindedir. Avrupa Birliği aktörleri (devlet ve hükümet başkanları, Konsey, Komisyon, Parlamento) ise, bir Temel Haklar Şarti'nın Avrupa Birliğini kimleyen en önemli unsur olduğunu ve bunun Avrupa Birliğinin kabulü ve meşruluğunun güçlenmesinde büyük katkı sağlayacağını düşünmektedirler (STEPPACHER, 2000: 2-3). Eleştiri yöneltenlerin bir kısmı Şart tamamlandıktan sonra eleştirilerinden vazgeçmiş ve Sart'ı iyi bir uzlaşma olarak kabul etmişlerdir. Buna karşılık, eleştiri yönelten diğer aktörler eleştirilerini sürdürmüşlerdir (ENGELS, 2001: 13 vd.; DAEUBLER-GMELIN, 2000: paragraf 34; STEPPACHER, 2000: $2 \mathrm{vd}$.):

1. Konvansiyon, kamuoyunun geniş bir şekilde katılımı için çaba harcamakla birlikte, Şart'ın ortaya çıkıs sürecinin temposunun sivil toplum aktörleri için çok yüksek düzeyde olduğunu not etmektedirler. Özellikle küçük çaptaki hükümet dişı kuruluşlar, kendi görüş ve düşüncelerini bildirme şansına sahip olamamışlardır.

2. Şart'ın Avrupa Konseyi'nin zayıflamasına yol açacağı ve böylece AİHS yoluyla oluşturulan standartların tehlikeye düşeceği ileri sürülmüştür. Bu eleştiri daha çok Avrupa Konseyi ve İngiltere'den gelmiştir.

3. Bugüne kadar Şart'ın "yetki emici bir etki"ye sahip olacağından endişe duyulmuştur. Bundan dolayı bu yöndeki görüş sahipleri Şart'ın hukuki bağlayıcılığının AB-yetki kataloğunun oluşturulmasına bağlamak istemişlerdir.

4. Eleştiri yöneltenlerin bir kısmı öncelikle sosyal hakların Şart'a alınmasına karşı şiddetle mücadele etmişlerdir. Aynı zamanda bir "sol eleştirisi" de yapılmıştır. Bu çerçevede Şart'ta yer alacak olan sosyal hakların zayıf şekilde düzenlemesi gerektiği ifade edilmiştir. Böylece Şart, neo-liberalizmin galibiyetini göstermiş olacaktır. Bunun açık bir işareti olarak Şart'ın 16. maddesinde yer alan ve bugüne kadar pek bilinmeyen "teşebbüs hürriyeti" gösterilebilir. Bu görüş sahipleri Şart'ın hukuken bağlayıcı nitelikte olmasına karşıdırlar.

5. Yukarıda en son belirtilen eleştiri ile ilişkili olarak, özellikle İskandinav ülkeleri tarafından dile getirilen endişeler ortaya çımıştır: Bu ülkeler kendi yüksek sosyal standartları, Şart sonucu daha düşük düzeyde uyum sağlanacağ tehlikesini görmektedirler.

6. Şart'ı eleştirenlerin bir kısmı, Şart'ın bazı maddelerindeki bir tehlikeye işaret etmektedirler: Şart'in çeşitli maddelerinde "insan" ve "kişi" ayrımı yapılmak suretiyle yaşama layık yaşam-yaşama layık olmayan yaşam ayrımına gidilmesinden endişe duyulmuştur. Bazıları ise, Şart'ın 3. maddesindeki 
klonlama yoluyla yeniden üretim yasağının yeni gelişmeleri de kapsayacak şekilde düzenlenmediğini belirtmektedirler (STEPPACHER, 2000: 4).

7. Medya temsilcilerinin bir kısmı, Şart'in 11. maddesindeki basın özgürlüğü ile ilgili düzenlemede yer alan "saygı gösterir" ifadesinin yeterli olmadığını, "güvence altına alınmıştır" deyiminin kullanılması gerektiğini belirtmişlerdir (ENGELS, 2001: 13).

8. Şart'a yöneltilen bir diğer eleştiri de, Temel Haklar Şartinun hukuki bir metin için çok fazla program hükümler içerdiği şeklindedir (DAEUBLERGMELIN, 2000: paragraf 34).

\section{GÖRÜŞLER \\ VII. ŞARTIN HUKUKi BAĞLAYICILIĞI: LEHINDE VE ALEYHINDE}

7 Arahk 2000 tarihinde Şart'ın törensel şekilde ilan edilmesiyle birlikte Avrupa Parlamentosu, Konsey ve Komisyon önemli bir politik irade ortaya koymuşlar ve Avrupa Birliği'nin temel haklar ve insan haklarıyla bağlı olduğunu yeniden vurgulamışlardır. Kuşkusuz ilan edilmekle Şart hukuki bağlayıcllık kazanmış değildir. Sart'ın hukuki açıdan bağlayıcı olabilmesi için AB Antlaşmalarının parçası haline gelmesi gerekmektedir. Şu andaki durumda Birlik vatandaşları Birliğin yürütme ve yasama işlemlerine karşı Şart hükümlerini ileri süremezler. Ancak, gittikçe artan bir ölçüde Şart'ın bağlayıcı nitelikte olması talep edilmektedir. Daha Şart'ın hazırlanması sürecinde Şart'ın - Nice zirvesinde Antlaşmalara dahil edilmesi yönündeki görüşler belirli bir ağırlı̆ga sahipti. Almanya'da mümkün olan en kısa zamanda Şart'ın hukuki bağlayıch h̆ga sahip olması gerektiği konusunda uzlaşma sağlanmıştır. Avrupa Parlamentosu ve Komisyon da, üye devletlerin çoğunluğu da, sivil toplum ve bilimsel çevrelerin ağırlıklı bir kesimi de bağlayıcı olması taraftarıdır. Hiç kuşku yok ki, Temel Haklar Şartı'nın hazırlanması ile ilgili Köln kararı, ancak hukuki bağlayıcllı sorununun ileriyc bırakılması halinde gerçekleştirilebilmiştir. Bir başka deyişle, Şart projesinin gerçekleştirilmesinin hukuki bağlayıcllk konusunda tıkanmaması için bağlayıchlık konusu ileriye bırakılmıştır. Özellikle Ingiltere, Irlanda ve İsveç, hala Şart'm bağlayıd nitelikte olmasına karşı çıkmaktadırlar (ENGELS, 2001: 14).

Şart'ın hukuken bağlayıcı olmasına karşı çıkanlar veya kuşkuyla bakanlar temclde üç argüman ileri sürmektedirler (ENGELS, 2001: 14):

1. Eğer Avrupa Birliği Adalet Divanı bir temel hakkın ihlalinden Birliğin bir işlem yapması zorunluluğunu çıkarırsa, Temel Haklar Şartı yetki emici bir etkiye sahip olacaktrr.

2. Ulusal anayasal hükümler, Şart'in bazı maddelerinde yer alan hükümlerden daha geniş bir içeriğe sahiptir. Bu noktada ulusal temel hakların zayıflamasından korkulmaktadır. 
3. Avrupa Birliğinin AIHS'ni onaylaması bireyler için yeterli bir koruma sağlayacağı gibi, Avrupa Birliği çerçevesinde kabul edilecek paralel bir temel haklar sisteminin Avrupa Konseyi temel haklar rejimini zayıflatmasınin da önüne geçilmiş olacaktır.

Temel Haklar Şartı hukuki açıdan bağlayıcı nitelikte olmasa da, Avrupa Birliği Adalet Divanı'nun gelecekte $A B$ Antlaşması'nun 6 . maddesini yorumlarken Sart'tan yararlanabilecektir. Zira bu maddede, AtHS ve üye devletlerin anayasalarında yer alan haklar gibi temel haklar ve insan hakları daha önce tanınmış bulunmaktadır. ABAD bugüne kadar zahmetli bir iş olan mukayeseli hukuk yöntemini kullanarak üye devletlerin ortak anayasal düzenlemelerinden yararlanmasında olduğu gibi, ilan edilmesinden sonra Şart hükümlerine de dayanabilir. Zira Şart, ortak anayasal düzenlemelerin bir ürünüdür.

Bununla birlikte, AB Antlaşmalarına dahil edilmediğinde Şart'nn yalnızca Avrupa'nın "soft law"ı olacağı ve Birliğin tedbirlerine karşı bireylere ABAD'na doğrudan başvuru hakkı tanımayacağı gerçeğini değiştirmemektedir. Bundan dolayı hukuki açıdan bağlayıcı olmasını savunanların görüşlerine göre, Şart'ın sade bir bildirge olarak ilanı yalnızca ilk adım olmalıdır. Bu görüşü savunanlar, Şart'in hukuken bağlayıcı nitelikte olmasını beş sebebe bağlamaktadırlar (ENGELS, 2001: 15):

1. Federal Almanya'daki anayasa şikayeti müessesesinden elde edilen tecrübeler göstermektedir ki, Federal Anayasa Mahkemesi bu yolla çok sayıda bireysel başvuruyu incelemiş ve vatandaşlar sahip oldukları anayasanın içeriği konusunda bilgi sahibi olmuşlardır. ${ }^{3}$ Anayasa şikayeti, bireylere anayasaya dayanarak kendilerini devlete karşı koruma imkanı sağlamaktadır. Avrupa Birliği devlet ve hükümet başkanlarının da arzu ettikleri gibi, Avrupa vatandaşlarının kendilerini Avrupa projesiyle özdeşleştirmelerinde Şart'ın katkı sağlaması isteniyorsa, Şart'ın hukuken bağlayıcı olması zorunlu bir şarttır (STEIN, 2001: 97).

2. Üye devletlerin parlamentoları tarafından kabul edilen ulusal yasaların büyük çoğunluğu Avrupa hukuku ile uyumlu hale getirilmiştir. Ulusal hukukun $A B$ hukuku ile uyumlu olması sorunu karşısında ortaya çıan önemli bir sorun da, temel haklarm korunması konusunda $A B$ hukukunun ulusal anayasalar ile karşılaştırılabilir bir koruma sağlayıp sağlamadığıdır. Temel hak korumasının önemli bir parçasını, bireylerin kendilerini devletin müdahaleleri-

3 Anayasa şikayeti müessesesinin Alman anayasa yargısındaki önemini şu veriler daha iyi göstermektedir: 7 Eylül 1951-31 Aralık 2000 tarihleri arasındaki yarım asırlık dönemde Federal Anayasa Mahkemesine toplam 132.002 dava açlmıştır. Bunlardan 126.962'si anayasa şikayeti, $3.288^{\prime} \mathrm{i}$ norm denetimi ve $5^{\prime} \mathrm{i}$ de siyasi parti kapatma davasıdır. Karara bağlanan 129.542 davadan 124.620 'si anayasa şikayeti başvurusu olup, bu başvurulardan 3.179 'u (\% 2,6) başarıya ulaşmıştır. Sonuçlanmamıs olan 2.460 davadan 2.342 'si anayasa şikayeti, geriye kalan 83 dava da norm denetimine ilişkindir (WASSERMANN, 2001: 201). 
ne karşı bireysel başvuru yoluyla koruması imkanının tanınması oluşturmaktadır. Ancak, bunun AB'nin hukuki işlemlerine karşı uygulanması çok güçtür.

3. Bundan dolayı, Avrupa bütünleşmesinin gelmiş olduğu konumda temel hak korumasınun da etkili bir usulle güçlendirilmesi gerekmektedir. Böylece Avrupa Birliği'ne yöneltilen eleştirilerden biri olan "demokrasi açğı" büyük ölçüde kapatılmış olacaktır.

4. Temel Haklar Şartı'nun şeffaf ve sivil toplumun geniş ölçüde katılımı ile hazırlanması, bu belgenin önemini artırmaktadır. Avrupa parlamenterlerinin ve halkın çoğunluğu Şart'ın hukuken bağlayıcı olmasını arzu etmelerine rağmen, hükümetler bunu engellerse, bu halde garip ve demokrasi öncesi dönemleri hatırlatan bir durum ortaya çıacaktır.

5. Şart'ın hukuki bağlayıcılık gücüne sahip olması, ulusal anayasaların koruma düzeyini zayıflatmayacaktır. Şart'ın yetki emici bir etkiye sahip olması yolu açıkça kapatılmıştır. AB'nin halihazırda sahip olduğu yetkiler dikkate alındı̆̆ında AiHS koruyucu bir enstrüman olarak yeterli değildir (ENGELS, 2001: 15).

Şart'ın hukuki açıdan bağlayıcı olmasını savunanların görüşlerine bakıldığında, Sart'ın "özel" bir usulle Antlaşmaların parçası haline gelmesini istedikleri görülmektedir. Bugüne kadar Antlaşma değişiklikleri ulusal parlamentolar tarafından onaylanmadan önce hükümet zirvelerinde görüşülmekte ve kararlaştırılmaktadır. Temel Haklar Şartı hükümet merkezli bu usulü yeniden gözden geçirme imkanı sunmaktadır. Bu konuda çeşitli öneriler ortaya atılmıştır. Bunlardan biri de, Şart'ın Avrupa ölçeğinde yapılacak bir referandum yoluyla Antlaşmalara dahil edilmesidir. Şart'ın bağlayıcılık kazanması Birlik vatandaşlarınca kararlaştırılırsa, bu, Şart'ın taşıdığı özel önemden dolayı Avrupa joplum sözleşmesinin temeli üzerinde tam bir mutabakatin olduğunu gösterecektir (PERNICE, 2000: paragraf 42).

Böyle bir usul gerçi $A B$ Antlaşmalarında öngörülmüş değildir. Ancak, bu durum, siyasi irade bulunduğunda devlet ve hükümet başkanları tarafından ulusal parlamentoların onayl ile birlikte değiştirilebilir.

Böyle bir referanduma gidilmesi kararlaştırıldığında hazırlık sürecinde hükümctlere, parlamentolara, siyasi partilere, medyaya ve hükümet dışı kuruluşlara Şart'ın içeriği hakkında halkı aydınlatma yükümlülüğü doğacaktır.

\section{TEMEL HAKLAR ŞARTI'NIN AVRUPA INSAN HAKLARI
SÖZLESMESI ILE iLISKISI}

Avrupa Birliği Temel Haklar Şartı'nın AliHS ile ilişkisi -ki ABA m. 6/2'de AilHS'ne riayet edilmesi gerektiği açıkça $A B$ 'nin yükümlülüğü olarak düzenlenmiştir- bütünüyle problemsiz bir şekilde oluşturulmuş değildir. Şartın 
52. maddesinin 3. fıkrasında yer alan düzenlemeyle Şart ile AIHS arasında uyum sağlanmaya çalışılmıştır. Şöyle ki, AİHS ile güvence altına alınan haklara uygun olarak Sart'ta yer alan hakların aynı öneme ve etkiye sahip olduğu ilkesi kabul edilmiştir. Bu düzenlemeden çıkan bir diğer sonuçta, Şart'ın bazı maddelerinde "kişi" ve "insan" kavramlarının doğru bir şekilde kullanılmamasından kısıtlayıcı bir sonucun çıkmayacağıdır. Bu yargı hiç kuşkusuz Birlik haklarının daha etkin şekilde korunması yönündeki amaca, ikinci flkrada vurgulandığı gibi, aykırı düşmez. Konvansiyon başkanlığının 20.9.2000 tarihli metnine eklenen gerekçede, Şart'ta yer alan hakların AİHS'nde yer alan haklarla aynı öneme ve etkiye sahip olduğu ifade edilmiştir. 53. maddede, Şart'ta yer alan hükümlerin AİHS ile güvence altına alınan hakları kısıtladığı veya olumsuz şekilde etkilediği şeklinde yorumlanamayacağı vurgulanmıştır (TETTINGER, 2001: 1011-1012).

Temel Haklar Şartı'nın hazırlanması sürecinde Avrupa Konseyi ve bazı üye devletlerin hükümetleri (örneğin İngiltere), Şart'ın kabulü sonucu Avrupa Konseyi sisteminin zayıflayacağını ve Avrupa'da iki farklı temel hak standardının ortaya çlkacağını ileri sürmüşler ve bu konudaki endişelerini dile getirmişlerdir. Temel Haklar Şartı bu endişeleri tamamen olmasa da, büyük ölçüde gidermiştir. AïHS, temel hakların korunmasında ulusal sistemi tamamlayıcı nitelikte uluslararası bir enstrüman iken, Temel Haklar Şartı, AB organlarını bağlar ve $\mathrm{AB}$ sisteminin parçasıdır. Ayrıca, ABAD'nın bugüne kadar ki temel hak içtihadı sonucunda, ne Avrupa Konseyi sistemi tehlikeye düşmüş ne de Strasburg'daki İnsan Hakları Mahkemesi gereksiz görülmüştür. ABAD, bugüne kadar ki uygulamasında AİHM'nin içtihatların büyük ölçüde benimscdiğinden, Avrupa'da iki ayrı temel hak standardının ortaya çıması söz konusu olmamıştır. Bu uygulamayı onaylamak için Şart metninde AIIHS'nin özel önemi vurgulanmıştır (ENGELS, 2001: 5).

Bununla birlikte Lüksemburg, Strasburg ve ulusal anayasa mahkemeleri arasındaki Bermuda Üçgeninde, ABAD ve AİHM'nin gelecekte kurulması zorunlu "işbirliğgi ilişkisi"nin nasıl oluşturulacağ çözülmesi gerekli bir sorun olarak ortada durmaktadır (TETTINGER, 2001: 1012; LIMBACH, 2000: paragraf 7). Nitekim Türk Dışişleri Bakanı İsmail Cem de, Temel Haklar Şartı konusunda yaptığı bir açılamada bu soruna değinmiştir. Cem, Avrupa İnsan Hakları Sözleşmesi çerçevesinde bir hukuki alanın zaten bulunduğuna işaret ederek, Temel Haklar Şartı'nın AB içinde bir politik deklarasyon niteliğinde olduğunu, Antlaşmaların hukuki parçası haline gelmediğini belirtmiştir. Temel Haklar Şartı'nın Antlaşmaların hukuki parçası haline gelmesi halinde, "ister istemez bu alanda Strasburg'dakine paralel yeni bir hukuki alan daha meydana getireceği" uyarısında bulunan İsmail Cem, iki değişik yerde oluşan hukuki alanların sakıncalı olabileceğine ve Strasburg'daki hukuki alanın yara alabileceğine işaret etmiştir. Cém, $A B$ nde ikinci bir hukuki alan oluşturmanun, $A B$ üyesi olan ve 
olmayan ülkelerin vatandaşları arasında bir çifte standart ortaya çıkarabileceğini vurgulamıştır (http://www.mfa.gov.tr/turkce/grupc/cb/2001/05/09052001. $\mathrm{htm}$ ).

\section{MI?}

\section{TEMEL HAKLAR ŞARTI, AVRUPA ANAYASASI'NIN TEMEL TAŞI}

Avrupa Birliği Anayasası ile ilgili görüşleri, tartışmaları ve gelişmeleri incelemek bu çalışmanın boyutunu aşmaktadır. Bu nedenle burada sadece genel bir tablo çizilecek ve Temel Haklar Şartı'nın rolüne değinilecektir.

Avrupa Birliği, yarım asır süren bir suskunluktan sonra bir yllı aşan bir süreden beri Avrupa Birliği Anayasasını ciddi şekilde tartışmaktadır. $A B$ Konseyi, 14-15 Arahk 2001 tarihinde yapılan Laeken zirvesinde bu tartışmayı yapısal bir zemine oturtmuştur. Bu zirvede bir konvansiyon kurulması kararlaştırılmıştır. Konvansiyonun oluşumunda, daha önce Temel Haklar Şartı'nı hazırlayan Konvansiyon oluşturulurken uygulanan yöntem örnek alınmıştır. Konvansiyon 1 Mart 2002 tarihinde çalışmalarına başlamıştır. Konvansiyon çalışmaların bir yıl içinde tamamlayacak ve bir tasarı ortaya koyacaktır. Tasarı ve anayașa tartışmaları 2004 yllında yapulacak olan zirvede ele alınacaktır.

Son on yilda yapılan hükümet zirvelerinin hepsinde demokratik meşruiyet, katılım, etkinliki ve vatandaşlara yakın olma konuları, Avrupa Birliği'nin ev ödevi olarak kabul edilmiştir. Nice zirvesinde Birliğe girecek yeni üyelerle işbirliği için gerekli olan teknik şartlar belirlenmiştir. Bu bağlamda "Avrupa Birliği'nin Geleceği" konusuna odaklanılmış ve Konvansiyona bu konuda dört önemli görev verilmiştir (NEUSS, 2002: 9-10; FES, 2002: 1):

1. Yetki ikamesi (subsidiarite) ilkesine uygun olarak $A B$ ile üye devletler arasındaki yetki paylaşımını belirlenmesi ve sınırların açıkça gösterilmesi.

2. Temel Haklar Şartı'nın statüsünün belirlenmesi.

3. Antlaşmaların basitleştirilmesi.

4. AB'nin yaplanmasında ulusal parlamentoların rolünün açklığa kavuşturulması.

Her ne kadar Avrupa Birliği Anayasası ile ilgili tartışmalar Laeken zirvesinden sonra artmış ise de, aslında bu tartı̧̧ma Temel Haklar Şartı projesiyle başlamıştır. Bir başka deyişle, Şart, Avrupa Anayasası tarışmalarına kapı aralamıştır (DI FABiO, 2000: 737). Gerçekten, Temel Haklar Şartı, demokratik hukuk devleti anayasasının kriterlerine uygun Avrupa Birliği Anayasası yönünde atılmış önemli bir adımdır. Her ne kadar Avrupa Topluluğunu kuran kurucu antlaşmalar, Topluluk organlannun faaliyetlerinin 
hukuki ölçüsünü teşkil etmesi anlamında bir anayasa gibi kabul edilse bile, bunun dışında bir anayasanın ayrıca demokratik iradenin oluşumu, kuvvetler ayrılığı ve temel hak koruması ile ilgili hükümler de içermesi gerekir. Avrupa Birliği, bir devlet değildir ve bundan dolayı bir devlet-anayasasına intiyacı yoktur. Ancak, Avrupa Birliği de kamu gücü kullanmakta ve bu kamu gücünün bir devlet düzeninde olduğu gibi meşrulaştırılması ve sınurlandırılması gerekir. Avrupa Birliği hala bu noktadan uzaktadır. Bu açıdan bakıldığında Temel Haklar Şartı'nın bu yolda dikkate değer bir adım olduğu söylenebilir (ÖHLINGER, 2000: 171).

Avrupa Anayasası tartışmalarında temelde ụ̧̈ farklı duruş ortaya çımmaktadır (ENGELS, 2001: 16):

Karşı Olma: Avrupa Birliği'nde "Avrupa süper devleti" olma eğilimi bulunmadığı için, Avrupa Birliği'nin bir anayasaya ihtiyacı yoktur. Hatta, böyle bir süper devlet, Avrupa vatandaşları için zamanla ulusal devletleri sorgulamada önemli bir referans teşkil edeceği için reddedilmelidir.

Olumlu Bakma: Avrupa Birliği'nin şu anki bütünleşme konumunda bir anayasanın kabulü ileriye dönük mantıklı bir adımdır ve özellikle açıklık şartının bir gereğidir. Zira, yalnızca açıklık şartıyla Avrupa'nın kendi içindeki karar alma prosedürleri uygulanabilir bir niteliğe bürünecek ve Avrupa böylelikle yalnızca elitlerin değil, vatandaşların Avrupa'sı da olacaktır.

Önemsiz Bulma: Avrupa Birliği, zaten yürürlükteki Antlaşmalar ile bir anayasaya sahiptir. Temel Haklar Şartı'nı ilan edilmesiyle de bu anayasa tamamlanmıştır. Kodifiye edilmiş, yani sistematik şekilde düzenlenmiş anayasal bir belgenin olması çok büyük bir öneme sahip değildir.

Bu görüşlerin ayrıntısına girmeksizin öncelikle anayasaların ne gibi bir fonksiyona sahip oldukların belirtmek faydalı olacaktır. Temelde bir anayasanın iki fonksiyonu vardır:

1. Esas olarak bir anayasa bir toplumun nasıl yönetildiği konusunda bilgi verir. Bir kararın alınmasında kimin hangi hususlarda yetkili ve sorumlu olduğu ve bu hususta hangi usullerin öngörüldüğü açıkça anayasada gösterilmelidir. Demokrasilerde ayrica bu yetkilerin ve usullerin mümkün olduğunca basit uygulanabilir şekilde formüle edilmesi tercih edilir. Her ne kadar anayasa kavramı, tek bir anayasal belgenin bulunması zorunluluğunu içermese de, anayasal hükümlerin tek bir belgede toplanması, ilgililerin gerektiğinde sadece tek bir metne bakarak bilgi edinmesini kolaylaştıracaktır.

2. Bir anayasa yetki paylaşımı yanında -kıta Avrupa'sı anlayışına göre- bir toplumun değerlerini ve siyasi iktidarı sınırlandıran temel hakları da içerir. Devlet faaliyetleri temel haklara uygun olduğu sürece meşrudur. 
Bu açılamalardan Avrupa anayasasının iki unsuru içermesi gerektiği sonucu çıkmaktadır (ENGELS, 2001: 16):

1. Avrupa Birliği organları arasındaki yetki düzeninin açıkça belirlenmesi, özellikle de Parlamento, Konsey ve Komisyon arasındaki yetki paylaşımı (dikey yetki paylaşımı) ve Avrupa Birliği ile üye devletler ve bölgeler arasındaki yetkilerin nasıl paylaştırılacağının tespiti (yatay yetki paylaşımı) önem arz etmektedir. Mevcut AB Antlaşmaları Birlik içerisindeki dikey ve yatay yetki konusunda hükümler içermektedir. Ancak, bu hükümler farklı antlaşmalarda yer aldığından uzmanlar tarafından bile bilinmesi ve uygulanması güçlük teşkil etmektedir. Bu yüzden Nice zirvesinde, gelecek hükümet zirvesinde Antlaşmaların basitleştirilmesiyle meşgul olunması da kararlaştırılmıştır.

2. Böylc bir anayasanin bütün erkleri bağlayıcı ve mümkünse bireylere doğrudan dava açma hakkı tanıyan bir temel haklar şartına ihtiyacı vardır. Temel Haklar Sartı, antlaşmalara dahil edildiğinde, bir anayasada bulunması gereken bütün unsurlar gerçekleşmiş olacaktır.

Avrupa Birliği Parlamentosu 18 Aralık 1999 tarihli kararında bir Temel Haklar Şartinun hazırlanmasını, gündeme gelen anayasa projesinin bütünleştirici unsuru olarak nitelendirmiştir. Temel Haklar Şartı ile birlikte, hem $A B$ Antlaşmalarının anayasal karakteri güçlenmekte hem de bireylerin daha fazla bilinçlenmesi sağlanmaktadır. Temel Haklar Şartı, AB Antlaşmalarına dahil edildiğinde ortak para birimine geçișten sonra Avrupa Anayasası sürecindeki en önemli adım olacaktır (PERNICE, 2000: paragraf 5)

\section{TEMEL HAKLAR ŞARTI VE TÜRKIYE}

Temel Haklar Şartı'nın ilan edilmesi ile birlikte, Şart'ın Birliğge girecek aday ülkeler için yeni birtakım yükümlülükler getirip getirmediği sorusu gündeme gelmiştir. Şart, băğlayıc hale gelmeden böyle bir soruya verilecek cevap olumsuz olacaktır. Buna karşılık Şart'ın bağlayıcı hale gelmesi durumunda bile, Sart'taki pek çok hükmün daha önceden değişik Topluluk düzenlemelerinde olması nedeniyle pek de önemli bir değişiklik olmayacaktır (TEZCAN, 2002: 264). Komisyon, Temel Haklar Şarti'nın aday ülkelere önemli yükümlülükler getiren bir enstrüman olmadığını belirtmiştir. Temel Haklar Şartı daha ziyade hem aday ülkelerin hem de genel olarak vatandaşların yararına olan temel hak normlarının açıklığını sağlamaya ve hukuk güvenliğini artırmaya katkıda bulunmaktadır. Komisyon ayrıca Şart'ın üye devletlerde bir anayasa değişikliğini gerekli kılmadığını da vurgulamıştır (KOMISYON, 2000: paragraf 13-14).

Temel Haklar Şartı, aday ülkelerin insan haklanı alanundaki çalışmalarını ve hazırlıklarını hangi çerçeve içinde yapmaları gerektiği hususuna açıklık 
getirmektedir. Aday ülkeler Şartı, AB müktesebatınun bir parçası olarak kabul etmek durumundadirlar (DAEBLER-GMELIN, 2000: paragraf 10). Dolayısiyla aday ülkelerin Avrupa Birliğine girişinde önem arz eden husus, kendi hukuk düzenlerini Avrupa Birliği müktesebatma uyumlu hale getirmeleridir. Zira, Şart bağlayıcı hale gelmese bile, Şart'ta yer alan hükümler yeni hükümler olmayıp, daha önceden Topluluk hukuku içerisinde yer alan düzenlemelerin derlenmesinden oluşmaktadır. Bundan dolayı, Şart, aday ülkeler tarafından dikkate alınması gereken temel belgelerden biridir. Insan haklarına saygı ilkesi Avrupa Birliğine üyelik için vazgeçilmez şartlardan biridir. Bunun bir sonucu olarak da aday ülkeler, katılım müzakerelerinin yapıldığ1 dönemde insan hakları ve temel özgürlüklerin geçerliliği ve korunması konusunda Avrupa temel hak standardına ulaşmış olmaları gerekir. Temel Haklar Şartı bu bağlamda aday ülkelere yol gösterici ve onları yönlendirici bir işleve sahiptir (HIRSCH, 1999: paragraf 39-43).

Temel Haklar Şartı, hukuki açıdan bağlayıcı nitelikte olmasa da, politik açıdan bağlayıcı olduğundan kuşku yoktur (SCHACHTSCHEIDER, 2001: 16). Bir başka deyişle bağlayıcı olmaması, belgenin siyasi ağırlı̆ını etkileyen bir unsur değildir. AB Temel Haklar Şartı, hukuki olarak bir Bildirge niteliğinde olmasına karşın, $A B$ 'nin en üst düzeyinde kabul edilip deklere edilen bir belge olarak $A B$ politikasının insan hakları ayağını oluşturması açısından son derece büyük önem taşımaktadır. AB Konseyi, Komisyon ve Parlamento tarafından onaylanan bu belge $A B$ tarafından iç ilişkilerinde temel başvuru kaynağ olma yanunda aday ülkeler için de Kopenhag Zirvesinde belirlenen insan hakları kriterlerinin ne anlama geldiğini tespite yarayan bir metindir. Nitekim, Konvansiyon üyesi Guy Braibant, Temel Haklar Şartı'nın aday ülkeler için AB'ye giriş bileti anlamına geldiğini, aday ülkelerin AB'ye girmek istiyorlarsa Temel Haklar Şartı'na uymaları gerektiğini ifade etmiştir (SABAH, 16 Ekim 2000).

$A B$ adayı olan Türkiye'nin bu çerçevede üzerine düşen yükümlülük, anayasal düzenini Temel Haklar Şartı'na uyumlu hale getirmektir. Bu yapılırken AIHS ve AiHM içtihatlarının dikkate alınması yararlı olacaktır.

\section{SONUÇ}

Avrupa Parlamentosu'nun 1989 ve 1994 tarihlerindeki iki ayn girişiminin başarısızlıkla sonuçlanmasının, Topluluğun AIHS'ne katılımının Adalet Divanı tarafından AT Antlaşması'nda gerekli revizyon yapılmadan mümkün olmadığının belirtilmesinin ve üye devletler arasında bu konuda gerekli uzlaşmanın sağlanamamasının ardından, 1999 yılının Haziran ayında yaplan Köln zirvesinde Avrupa Birliği Temel Haklar Şartı'nun hazırlanması gündeme gelmiştir. 
Temel Haklar Şartı, 7 Aralık 2000 tarihinde Konsey, Komisyon ve Parlamento başkanları tarafından imzalanarak törenle ilan edilmiştir. Şart, Avrupa Birliğine üye devletlerin ortak değerlerini ve ilkelerini içeren ve şu an için politik bir deklarasyon niteliğinde olan bir metindir. Şart'ın hukuki açıdan bağlayıcı niteliğe kavuşup kavuşamayacağı, 2004 yllında yapılacak devlet veya hükümet başkanları zirvesinde belirlenecektir. Bununla birlikte, Şart, Avrupa Parlamentosu, Konsey ve Komisyon tarafından imzalandığından kurumlararası ortak bir metin niteliğindedir. Dolayısıyla metni imzalayan kurumlar açısından Şart, bağlayıcı bir nitelik kazanmıştır. Komisyon'un da belirttiği gibi, bu kurumlar tasarruflarında Temel Haklar Şartı'nı bundan böyle görmezden gelemeyeceklerdir. Öte yandan Şart'in halihazırda Adalet Divanı açısından bağlayıcı olmamakla birlikte! bir esin kaynağı olacağı söylenebilir.

Temel Haklar Şartı, Avrupa Birliği'nin hukuki değerlerini yazllı olarak tespit etmektedir. Bu değerler hem Avrupa Birliği'ne girecek aday ülkeler için hem de Birliğin üçüncü ülkelere karşı yürüteceği insan hakları politikası için uyulması zorunlu bir temel teşkil etmektedir. Bir başka deyişle Temel Haklar Şart, Birliğin genişlemesi ve dış politika alanında etki doğuracaktır.

Temel Haklar Şarti, Avrupa Birliği çerçevesinde gerçekleştirilen adımların, demokratik ve moral meşruiyetini sağlama açısından önemli bir belgedir. Bunun yanı sıra, Şart, temel haklan sistematik hale getirdiğinden bireylerin haklarını tanıması ve bunları geçerli kılması kolaylaşmakta ve bunun bir sonucu olarak da temel hakların korunması düzeyi yükselmektedir. Nihayet, Temel Haklar Şartı, Avrupa Birliği Anayasası yönünde önemli bir adım teşkil etmektedir.

\section{Kaynakça}

CAVuŞOĞLU, N. (1994), Insan Haklan Aurupa Sözleşmesi ve Aurupa Topluluk Hukuku'nda Temel Hak ve Hürriyetler Ozerine (Ankara: AÜSBF Insan Hakları Merkezi Yayını).

ÇAvuşoĞlu, N. (1999-2000), "Avruja Topluluğu/Birligi'nin Insan Hakları Politikası," Insan Haklan Yılliğı, 1999-2000, Cilt 21-22:1:14.

DAEUBLER-GMELIN. H. (2000), "Eine Grundrechte-Charta für ein Europa der Bürgerinnen und Bürger," (www.whi-berlin.de/daeubler-gmelin.htm) (erişim tarihi: 6. 2. 2002).

DI FABlO. U. (2000), "Eine europaeische Charta," Juristen Zeitung. Heft 15/16, 11 August 2000: 737-743.

ENGELS, M. (2000). "Europaeische Grundrechtscharta als Spiegel des Europaeischen Modells?," FoodFirst 3/2000. FIAN-Magazin für die wirtschaftlichen, sozialen und kulturellen Menschenrechte (www.fian.de/foodfirst/food003.htm) (erişim tarihi:15. 3. 2002).

ENGELS, M. (2001). Die europaeische Grundrechtecharta: Auf dem Weg zu einer europaeischen Verfassung? Reihe Eurokolleg, 45 (2001), (Bonn: Friedrich Ebert Stiftung).

Friedrich Ebert Stiftung (FES) (2002), Für eine demokratische und handlungsfaehige EU: Empfehlungen für die Arbeil des Konvents (Bonn: Friedrich Ebert Stiftung. Arbeitspapier Nr. 11). 
HIRSCH, G. (1999), "Eine Grundrechtscharta für Europa? Die Grundrechtsfrage in der Perspektive der E(I-Erweiterung:", (www.whi-berlin.de/hirsch.htm) (erişim tarihi: 15. 05.2001).

KAKOURIS, C. N. (1990), "Hukuk Kuralları Hiyerarşisi Içinde Anayasa Kurallarının Yeri ve Topluluk Hukuk Düzeni lçinde Temel Hakların Korunmasındaki Anlamı," Avrupa Topluluğu Adalet Divanı Raporu, Anayasal Nomlar Hiyerarşisi ve Temel Haklann Korunmasındaki lşlevi, Cjlt 4 (Ankara: Anayasa Mahkemesi Yayını) (Cev.: A. Işeri): 29-49.

KOMISYON (2000), "Mitteilung der Kommission: zur Gundrechtscharta der Europaeischen Union-Vorlage von Herrn Vitorino im Einvernehmen mit dem Praesidenten," Brüksel, 13. 9. 2000, KOM (2000) 559 (www.eu-kommission.de/pdf/dokumente/charta.pdf) (erişim tarihi: 26. 2. 2002): 1-11.

UMBACH, J. (2000), "Die Kooperation der Gerichte in der zukünftigen europaeischen Gnundrechtsarchitektur: Ein Beitrag zur Bestimmung des Verhaeltnisses von Bundesverfassungsgericht, Europaeischem Gerichtshof und Europaeischem Gerichtshof für Menschenrechte" (www.whi-berlin.de/ limbach.htm) (erişim tarihi: 6. 2. 2002).

MAHLMANN, M. (2000), "Die Grundrechtscharta der Europaeischen Union," ZeuS, 3. Jahrgang, Heft 4/2000 (www.jura.uni-sb.de/projekte/Bibliothek/texte/Mahlmann.html) (erişim tarihi: 10. 3. 2002).

MARCUS-HELMONS, S. (2001), "Avrupa Birliğ Temel Haklar Şartı: Ortaya Çıkışı ve Sorunları," KABOĞLU, Ibrahim Ö. (edt.), Kopenhag Kriterieri: Aurupa Konseyi ve Aurupa Birliği'nin Ortak Paydası mi? (Istanbul: Istanbul Barosu lnsan Hakları Merkezi Yayını): 83-86.

NEUSS, B. (2002). "Die Krise als Durchbruch: Die EU zwischen Vertragsreform und Verfassungsentwurf," Inlernationale Politik, Januar 2002. Nr. 1: 9.16.

ODER. B. E. (2000), "Avrupa Bütünleşmesinin Temel Hak Boyutu," TANK(JTER, Korkut (edt.), Insan Haklan (Istanbul: Yapı Kredi Yayınları): 478-500.

ÖHUNGER, T. (2000), "Eine Grundrechts-Charta für Europa," Juridicum, Heft 3/2000: 170-178.

PERNICE, 1. (2000), "Grundrechte-Charta für die Europaeischen Union," DVBI, Heft 12, 2000: 1 vd. (www.rewi.hu-berlin.de/WHi/deutsch/papers/whipapers100/pernice.pdf) (erişim tarihi: 13. 12. 2001): 1.28 .

POLLAK, C. (1991), Verhaeltrismaessigkeilsprinzip und Grundrechtsschutz in der Judikatur des Europaeischen Gerichtsho/s und Osterreichischen Verfassungsgerichtshofs (Baden-Baden: Nomos Verlagsgesellschaft).

SCHACHTSCHNEIDER. K. A. (2001). "Eine Charta der Grundrechte für die Europaejsche Union," Recht und Politik. (37) $1 / 2001$.

STEIN, T. (2001), "Avrupa Birliği Ternel Haklar Şart," KABOĞLU, Jbrahim Ö. (edt.), Kopenhag Kriterleri: Aurupa Konsseyi ve Aurupa Birliğínin Ortak Paydast mi? (Istanbul: Istanbul Barosu Insan Hakları Merkezi Yayını): 93-100.

STEPPACHER, B. (2000), "Zum Entwurf einer Charta der Grundrechte der Europaeischen Union," (www.kas.de/publikationen/2000/europa/GRC-Analyse0009.pdf) (erişim tarihi: 25. 3.2002): $1-7$.

TETTINGER, P. J. (2001), "Die Charta der Grundrechte der Europaeischen Unjon", NJW, Heft 14/2001: 1010-1015.

TEZCAN. E. (2002), Aurupa Birliği Hukuku'nda Birey (Istanbul: lletişim Yayınları).

WASSERMANN. R. (2001). "Herr und nicht bloss Hüter der Verfassung: 50 Jahre Bundesverfassungsgericht," Recht und Politik, 4/2001: 200-204. 